\title{
IMPROVING THE ENGLISH HANDWRITING OF FIRST GRADERS THROUGH FINE MOTOR SKILLS INTERVENTIONS
}

\author{
Nadia Ali \\ Lecturer, \\ IER, University of Balochistan, \\ Balochistan, Pakistan \\ Email: nadia_barat786@yahoo.com
}

\section{Samreen Jalal}

Lecturer,

Department of Education, University of Education

Punjab, Pakistan

Email: $\underline{\text { samreen.jalal@ue.edu.pk }}$

\author{
Abdul Nasir Kiazai \\ Assistant Professor, \\ IER, University of Balochistan, \\ Balochistan, Pakistan \\ Email: mirnasir555@gmail.com
}

\begin{abstract}
Writing is an important aspect of learning the language and good writing becomes the source of success. Learning the techniques for improving the English handwriting are very important because these help to achieve pre-decided academic goals and moving from one class to the next class. Fine motor skills are related to movement of muscles by using hands and fingers properly. These skills contribute a lot in improving the English handwriting of students of first grade. This study was conducted by using the qualitative descriptive design and 4 boys (age: 6.5 years) of English Medium School (Milestone Public School) were selected as the participants of the study on the basis of their comparing handwriting patterns to the adapted rubrics and self-developed observation checklist. After that, researcher concluded their own observations about the collected writing samples. Data were collected through observation on the predefined observation parameters and practicing the fine motor skills in 3 weeks interventions. The findings of the study showed that these skills play very important role in improving the English handwriting of students and students observe refinement in their writing through provision of new information about the tools and techniques of fine motor skills, practicing of these skills and evaluating of these skills on daily basis according to set criteria. The recommendation of this study was that these skills
\end{abstract}


not only used for the improvement of English handwriting but also for Urdu and Counting handwriting.

\section{KEYWORDS}

Literacy and Numeracy Drive Project, Writing skills, Primary grade students, English and Urdu writing skills, Math's writing skills.

\section{INTRODUCTION}

Handwriting is linked with students' mental development and plays a very important role in students' academic achievement. Practice enables the students to get expertise in their writings. At junior level, different practical activities bring expertise to a certain level in students' handwriting (Guidelines for Handwriting Instruction, 2012). Objectives of teaching handwriting to students include: a) to enable the students to write the words in an appropriate way, b) to enable them to write the words speedily and independently, and c) to provide self-confidence on their writings (Handwriting in the 21st Century: An Educational Summit, 2012). These aspects are included in teaching handwriting to students at primary level that is learning about pencil grip, formation of letters, recognition of letters, speed in writing, and bring quality in writing (Renwick, 2008). Megaiab (2014) describes that learning of English language starts from primary level and the basic purpose of teaching English at this level is to increase students' skills in speaking and writing patterns and provide awareness about the importance of English. Four skills are introduced by teaching English that is listening, speaking, reading and writing. Listening and speaking are concerned with oral and reading and writing are concerned with creative work. Students have to develop these skills at the end of class one:

a) Recognition of English letters and write upper and lower case letters without any help.

b) Pronounce the letters with understanding.

c) Formation of letters accurately.

d) Independently write the dictated alphabets. (Snow, Burns, Griffin, 1998)

Students face a lot of difficulties in English handwriting that is recognition of alphabets, differentiating the alphabets, changing the words, writing upper case and lower case letters and formatting the alphabets according to their shape and size (Guidelines for Handwriting Instruction, 2012). According to Hill (2006) (as cited in Handwriting: Department of Education, 2016), the following stages of learning the English writing are:

\section{Beginning Writing}

In this stage, children express their opinions by making drawings and convey their written expressions in such a way. 


\section{Early Emergent Writing}

In this stage, children use the symbolic letters to present the alphabets and practice these alphabets by writing again and again.

\section{Emergent Writing}

In this stage, children write more alphabets by following the space pattern and practice theses to bring excellence in writing.

\section{Early Writing}

In this stage, children can differentiate between lower and upper case letters, space between alphabets and doubling-up of letters. At the stage of first grade, students have to be familiar with 26 capital and small alphabets, spacing between alphabets, shape of letter and tried to combine the alphabets.

Marr, Windsor \& Cermak (2001) describe the reasons of poor handwriting of students is not the development of fine motor skills accurately and teacher's approach to teach handwriting to students. Majority of students at primary level face problems in writing the correct formation of alphabets and the main reason of it no proper development of fine motor skills. Physical changes in child's hand and fingers bring the cause of variation in holding the pencil. Problems in handling the pencil are concerned with gripping the pencil too tightly and holding the pencil at writing point.

Pencil grip of students should be supervised and guidance should be provided to such students (Ministry of Education, 2007). Fine motor skills are comprised of smaller muscles movement with fingers and hands that is related to holding the pencil and different articles. Students may learn theses skills in schools by involving in the activities of cutting and learning the syllables by doing clapping (Cameron et al., 2012).

Teacher may use these strategies for learning the English handwriting of students:

1. Firstly, teacher has to learn the students about handling of pencil and teacher will also guide the students about sitting position at the time of handwriting.

2. Secondly, teacher can create group of students according to different ability level of students. Teacher will ask the students to write different words and students will share their learning to each other and help each other in learning the alphabets.

3. Thirdly, teacher has to allocate the specific portion of classroom for display of letters. Students will see these words and get understanding of these words in spare time.

4. Fourthly, teacher will use different colors pencil for teaching handwriting to students (Guidelines for Handwriting Instruction, 2012). 
Renwick (2008) describes the following components for improving English handwriting at first grade:

\section{Verbalization}

It means that students have to write the words in the lines appropriately. They have to start the word at proper place and end at proper point.

\section{Writing Format}

It is the teacher responsibility to provide instructions to students about handwriting movement.

\section{Exercises}

Teacher has to teach the words by using different exercises because these exercises will enable the students to grip the pencil, copy simple letters, recognition of letters and formation of letters.

Occupational and Physical Therapy Department (2009) describes the handwriting problems and their remedies. Problems related to don't write on the lines, irregular spacing between the lines, and don't have understanding about the borders. In these cases, teacher has to use the stop sign when students are copying from the board, use another page for writing when students having difficulty in writing on lines, and checklist for correcting the mistakes of students. Problem related to not holding the pencil appropriately and feels pain in writing. Teacher can overcome these problems by using different colors chalks and cutting with scissors.

Problem related to not write the correct construction of letters and teacher can join the same letters shapes (c, a, b, d) at the time of writing, giving verbal instructions to students, repeating the writing style of alphabets, and assigning the task in small groups. Schickedanz (1999) defines that learning of writing the letters is based on visual understanding of each alphabet, writing each letter in sequential form and on set pattern of lines. Dinehart (2015) describes that fine motor skills play an important role in students' achievement and become the source of improving students English writing skills. Different fine motor skills that are building blocks, stretching finger, firework, playing the piano facilitate in pencil grip and copying letters.

In stretching finger, the finger tips are to put together and then fingers are straightened against each other. In playing piano, children touch the table with the fingers one by one of both hands. At beginning, children touch the table slowly and getting faster after two or three times practice. By making a fist with both hands, holding it tightly and open the fires like the fireworks. 
Research reported by (Marr, Cermak, Cohn, Henderson, 2003) that uses of hands play very important role in writing. $46 \%$ of the whole time, students of first grade spend in the activities (playing piano, cutting with scissor, playing with fingers) of fine motor skills development and $42 \%$ in paper based pencil activities (Painting \& writing). Students spend their most of the time in fine motor skills development but little focus is allocated to study this aspect in aspect of the process of research.

On the basis of literature above, it can be concluded that fine motor skills play very important role in improving the English handwriting of students and the basic purpose of this study is the use of different fine motor skills interventions for improving the English handwriting of first grade children. Students face a lot of difficulties in writing of English language alphabets and not in a position to write according to set pattern. The reason is that they are not practicing the activities related to movement of hands and fingers and pencil grip. So the present study aims to improving the English Handwriting of First Graders through Fine Motor Skills interventions.

This study would be beneficial for students because the findings of the study would provide information of learning new techniques of English handwriting because handwriting is one of the important skills in aspect of written communication. It would be useful to the teachers because the results of the study would help the teachers in changing the teaching strategies and using the teaching aids appropriately for improving English handwriting of students. It would be helpful to the heads of institutions to improve the process of English writing skills among first graders by arranging different types of learning activities as well as facilitate the teaching-learning process for improving the English handwriting.

\section{RESEARCH OBJECTIVES}

1. To find out the existing level of English Handwriting of First Graders through rubrics and observation.

2. To evaluate the impacts of Fine Motor Skills interventions in improving the English Handwriting of First Graders

\section{RESEARCH QUESTIONS}

1. What is the existing level of English Handwriting of First Graders?

2. What are the impacts of Fine Motor Skills interventions in improving the English Handwriting of First Graders?

\section{RESEARCH METHODOLOGY}

This study was conducted by using the qualitative descriptive design with case study design because the purpose is to obtain rich information about the problem of study. 4 right handed students (Boys, age: 6.5 years) of class one of English Medium School 
(Milestone Public School) were selected as participants in this study. The School day starts at $8.00 \mathrm{am}$ and closes at $1.30 \mathrm{pm}$. Time for English writing is allocated 30 minutes. Students selected as participants of study had normal vision. Their names were changed to maintain the confidentiality and verbal informed consent was obtained prior to the study. Detail of participants was:

Zakir - He was 5.5 years old and he didn't attend the nursery class. He was a single parent child and cared by his grandmother He received guidance from home for completion of school homework. He was lacking fine motor skills and his writing was also illegible.

Abid - He was 6 years old and wanted to learn from other class fellows. He received guidance from parents.

Razaq - He was also 6 years old and physically very energetic. His teacher shared that he did not pay attention to complete his class work as he engaged in kidding and talking with other classmates. When he was asked about his class work, he tried to complete it in haste which no doubt affect his handwriting legibility. Also he had little guidance from home for completion of their school work.

Abdul Hadi - He was 6.5 years old and played with class fellows. His mother and tuition provided the support.

\section{Pre-intervention Phase}

In this phase, the researcher familiarized the school head about the intervention for improving poor handwriting of the students. Further it was requested to share the handwriting notebooks that are considered with having poor handwriting. The researcher had some reservation about the notebooks handwriting as it was felt that it was so guided by the teachers that we were unable to find poor handwriting that may be scored weak as per rubric.

Then it was decided that the researcher would develop the worksheets to collect the samples of handwriting on the basis as it is. During the collection of writing samples, the researcher was taking field notes while observing the movement and grip of pencil and recorded on the self-developed observation checklist. The sampled worksheets were collected and analyzed with the help of adapted rubric. It was noted after analysis and field notes that we need to conduct intervention with four students of one class.

\section{Observation Checklist}

\begin{tabular}{cc}
\hline Handwriting Parameters & Observation \\
\hline Grip on pencil & \\
Neatness & \\
Writing letters on lines & \\
Space in writing the letters & \\
\hline
\end{tabular}


Start and end the word at proper place

Comments and Plan further actions

Rubrics

\begin{tabular}{|c|c|c|c|c|c|c|}
\hline $\begin{array}{l}\text { Handwritin } \\
\text { g } \\
\text { Parameters }\end{array}$ & $\begin{array}{l}\text { Outsta } \\
\text { nding } \\
(5)\end{array}$ & Good (4) & Fair (3) & $\begin{array}{l}\text { Poor } \\
(2)\end{array}$ & Weak (1) & $\begin{array}{l}\text { Sco } \\
\text { re }\end{array}$ \\
\hline & $100 \%$ & $\begin{array}{l}\text { More from } \\
\mathbf{7 5 \%}\end{array}$ & $\begin{array}{l}50 \%- \\
75 \%\end{array}$ & $\begin{array}{l}25 \%- \\
50 \%\end{array}$ & $\begin{array}{l}\text { Less than } \\
25 \%\end{array}$ & \\
\hline $\begin{array}{l}\text { Starting of } \\
\text { letters at the } \\
\text { correct point }\end{array}$ & $\begin{array}{l}\text { Always } \\
\text { start at } \\
\text { correct } \\
\text { point }\end{array}$ & $\begin{array}{l}\text { Most of the } \\
\text { time start at } \\
\text { correct } \\
\text { point }\end{array}$ & $\begin{array}{l}\text { Some of } \\
\text { the time } \\
\text { start at } \\
\text { correct } \\
\text { point } \\
\text { (few } \\
\text { errors) }\end{array}$ & $\begin{array}{l}\text { Start at } \\
\text { correct } \\
\text { point } \\
\text { rarely } \\
\text { (some } \\
\text { errors) }\end{array}$ & $\begin{array}{l}\text { Start at } \\
\text { correct } \\
\text { point does } \\
\text { not } \\
\text { happen } \\
\text { (many } \\
\text { errors) }\end{array}$ & 5 \\
\hline $\begin{array}{l}\text { Closing of } \\
\text { letters at the } \\
\text { correct point }\end{array}$ & $\begin{array}{l}\text { Always } \\
\text { end at } \\
\text { correct } \\
\text { point }\end{array}$ & $\begin{array}{l}\text { Most of the } \\
\text { time close } \\
\text { at correct } \\
\text { point }\end{array}$ & $\begin{array}{l}\text { Some of } \\
\text { the time } \\
\text { end at } \\
\text { correct } \\
\text { point } \\
\text { (few } \\
\text { errors) }\end{array}$ & $\begin{array}{l}\text { End at } \\
\text { correct } \\
\text { point } \\
\text { rarely } \\
\text { (some } \\
\text { errors) }\end{array}$ & $\begin{array}{l}\text { End at } \\
\text { correct } \\
\text { point does } \\
\text { not } \\
\text { happen } \\
\text { (many } \\
\text { errors) }\end{array}$ & 5 \\
\hline Pencil grip & $\begin{array}{l}\text { Always } \\
\text { have }\end{array}$ & $\begin{array}{l}\text { Most of the } \\
\text { time }\end{array}$ & $\begin{array}{l}\text { Few of } \\
\text { the time }\end{array}$ & $\begin{array}{l}\text { Some } \\
\text { of the } \\
\text { time }\end{array}$ & $\begin{array}{l}\text { Do not } \\
\text { have }\end{array}$ & 5 \\
\hline $\begin{array}{l}\text { Words } \\
\text { Spacing }\end{array}$ & $\begin{array}{l}\text { All of } \\
\text { the } \\
\text { words } \\
\text { spaced } \\
\text { accurat } \\
\text { ely }\end{array}$ & $\begin{array}{l}\text { Most of the } \\
\text { time words } \\
\text { spaced } \\
\text { accurately }\end{array}$ & $\begin{array}{l}\text { Few of } \\
\text { the } \\
\text { words } \\
\text { spaced } \\
\text { accurate } \\
\text { ly }\end{array}$ & $\begin{array}{l}\text { Little } \\
\text { of the } \\
\text { words } \\
\text { spaced } \\
\text { accurat } \\
\text { ely }\end{array}$ & $\begin{array}{l}\text { Words not } \\
\text { spaced } \\
\text { correctly }\end{array}$ & 5 \\
\hline $\begin{array}{l}\text { Size } \\
\text { letters }\end{array}$ & $\begin{array}{l}\text { All of } \\
\text { the } \\
\text { letters } \\
\text { sized } \\
\text { correctl } \\
y\end{array}$ & $\begin{array}{l}\text { Most of the } \\
\text { letters sized } \\
\text { correctly }\end{array}$ & $\begin{array}{l}\text { Few of } \\
\text { the } \\
\text { letters } \\
\text { sized } \\
\text { correctl } \\
\text { y }\end{array}$ & $\begin{array}{l}\text { Little } \\
\text { of the } \\
\text { letters } \\
\text { sized } \\
\text { correctl } \\
y\end{array}$ & $\begin{array}{l}\text { Letters are } \\
\text { not sized } \\
\text { correctly }\end{array}$ & 5 \\
\hline $\begin{array}{l}\text { Understandi } \\
\text { ng of letters }\end{array}$ & $\begin{array}{l}\text { All of } \\
\text { the } \\
\text { letters }\end{array}$ & $\begin{array}{l}\text { Most of the } \\
\text { letters }\end{array}$ & $\begin{array}{l}\text { Few of } \\
\text { the } \\
\text { letters }\end{array}$ & $\begin{array}{l}\text { Little } \\
\text { of the } \\
\text { letters }\end{array}$ & $\begin{array}{l}\text { Letters are } \\
\text { not in }\end{array}$ & 5 \\
\hline
\end{tabular}




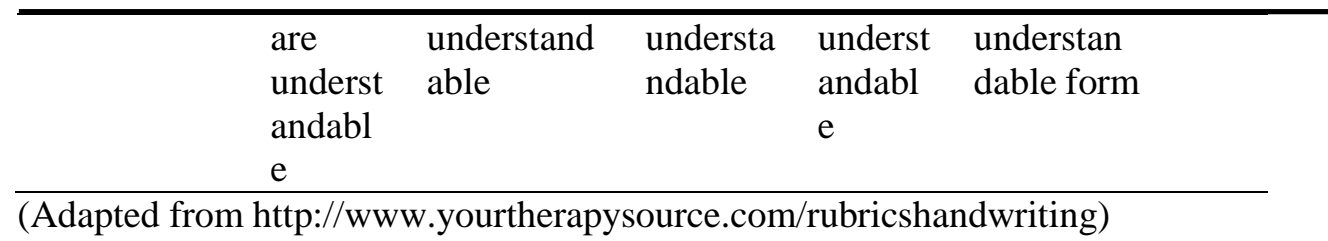

\section{Action Research Cycle}

Statement of the Problem: Improving the English handwriting of First graders

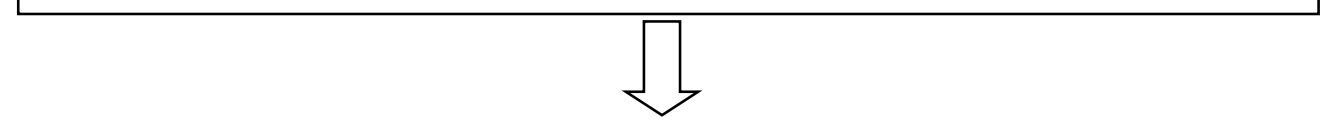

Data Collection: Collection of preliminary students writing samples
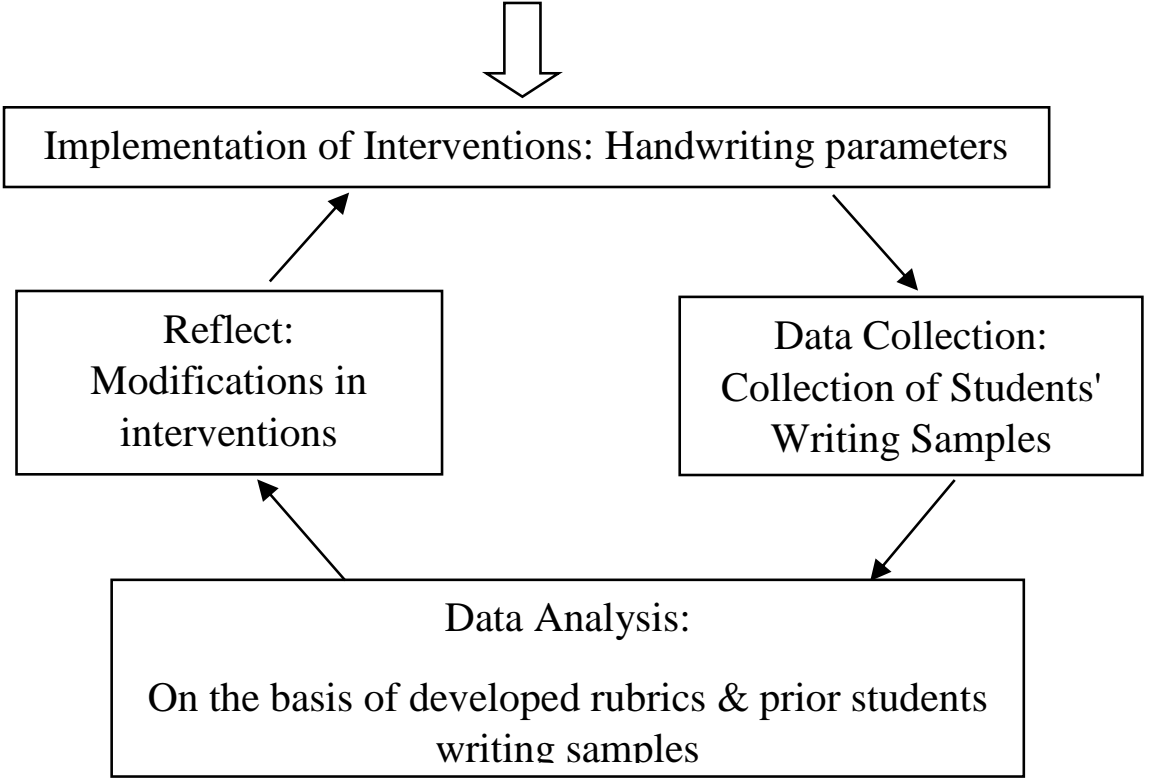

FINDINGS AND DISCUSSION

Observations of pre-intervention stage are:

\section{Case 1}

Zakir, the student of class one was selected as his grip on pencil was not proper; the letters were not properly sized and spaced as he did not differentiate to place the upper, middle and bottom case. He spent a lot of time to complete his writing task on worksheet. He was using eraser to erase the words again and again. He was getting 
help from other mates. He got scored 6 out of 30 for his writing performance by utilizing rubric.

\section{Case 2}

Abid, was student of class one. He was starting and ending the letters inappropriately. But his words and letters were properly spaced and sized with a poor pencil grip. He was scored 10 out of 30 for his writing performance by utilizing rubric.

\section{Case 3}

Razaq, student of class 1 . This case was little different from others as his writing was eligible when he was writing a sentences with having three to four words but as he was directed to write sentences having five to six words he lost to write in proper size and place as result his legibility of writing was decreased. He was scored 10 out of 30 for his writing performance by utilizing rubric.

\section{Case 4}

Abdul Hadi was also the student of class one. His writing was not legible as the words were not properly sized as well his starting and ending of letter formation was not proper. He got scored 12 out of 30 for his writing performance by utilizing rubric.

Following findings were drawn from pre-intervention stage:

Start at correct point did not happen (many errors and using eraser to correct the alphabets).

End at correct point did not happen (many errors and using eraser to correct the alphabets).

Words were not spaced correctly.

Letters were not sized correctly.

Letters were not in understandable form.

Grip of pencil was not proper and unable to differentiate the capital and small letters usage.

\section{Intervention Stage}

First Week of Drill

In order to address the above mentioned writing issues by review literature on improving handwriting. Some of Fine motor skills were selected to be experimented and find the impacts of these Fine motor skills on poor handwriting. These Fine motor skill activities were consisting of different modules. These activities as per given description was applied to these students. It was observed during the experiment, the students having poorer writing were having poorer motor skills when I looked upon back on the collected writing samples. These students were facing more difficulty to demonstrate the activities.

These activities include:

\section{Activities}

Instructions to the Activities

Observations 


\begin{tabular}{|c|c|c|}
\hline Stretching Finger & $\begin{array}{l}\text { At first, the finger tips were to } \\
\text { put together and then fingers } \\
\text { were straightened against } \\
\text { each other. This exercise was } \\
\text { repeated for five times. }\end{array}$ & $\begin{array}{l}\text { It was observed that one of the } \\
\text { students 'Zakria' was } \\
\text { struggling a lot in putting the } \\
\text { fingers together and } \\
\text { straightening the hands. So he } \\
\text { was given } 3 \text { more chances than } \\
\text { other to improve skill. After } \\
\text { repetitions, he got improved to } \\
\text { some extent but still needed } \\
\text { improvements. }\end{array}$ \\
\hline Playing the Piano & $\begin{array}{l}\text { By touching the table with } \\
\text { the fingers one by one of both } \\
\text { hands like playing piano. At } \\
\text { beginning, touching the table } \\
\text { slowly and getting faster after } \\
\text { two or three times. }\end{array}$ & $\begin{array}{l}\text { Here the students were } \\
\text { struggling a lot to touch the } \\
\text { table with fingers as the } \\
\text { students were using all the } \\
\text { fingers at a time. But after a } \\
\text { number of trails, they were } \\
\text { good. }\end{array}$ \\
\hline Fireworks & $\begin{array}{l}\text { By making a fist with both } \\
\text { hands and holding it tightly. } \\
\text { Open the fingers like } \\
\text { exploding the fireworks. It } \\
\text { was to repeat for five times. }\end{array}$ & $\begin{array}{l}\text { It was carried easily after } \\
\text { 3rd trial. }\end{array}$ \\
\hline
\end{tabular}

After the experiment, I also visited their classrooms and observed their seats and sitting postures that signaled me with another issue that is improper sitting posture due to extra distance between the chair and table which was hindering the students elbow to reach the table. As a result of this hindrance, the students had to stand on their feet to complete their writing tasks.

\section{$2^{\text {nd }}$ Week of Drill}

In the start of $2^{\text {nd }}$ week drill, the teacher of Zakir was really excited to share that the writing skills were so improved that he got STAR on his writing task. This was appreciated by the head of school as well. He requested me to train one of their teachers on these activities. It was also observed that the seats of these four students were changed and at this time, the students were writing more comfortably. At the end of week not only the writing of zakir but other 3 students had improved.

\section{$3^{\text {rd }}$ Week of Drill}

A number of improvements were observed in the writings of all four students. The following improvements were recorded as per their writing by utilizing the rubric; they were scored 16 to 12 out of 30 . 


\section{RESULTS}

\section{Case 1}

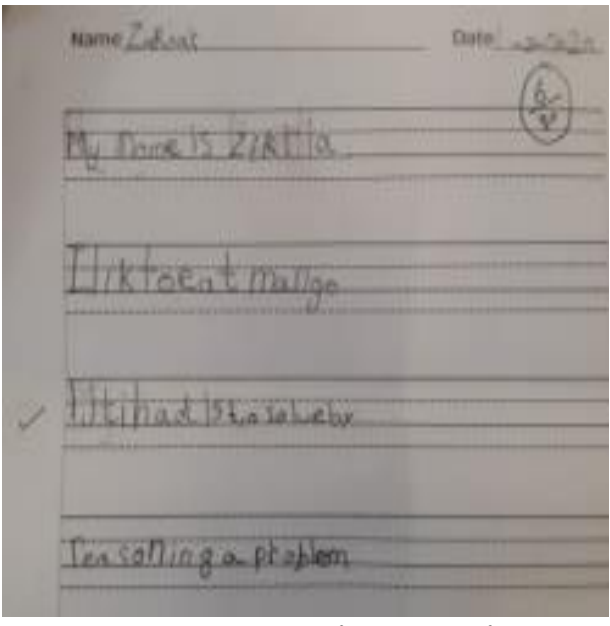

Pre-intervention

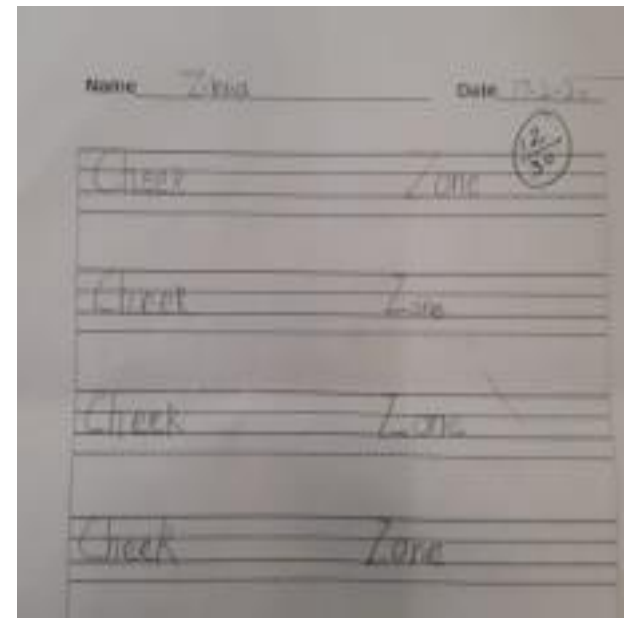

Post-intervention

Zakir, the student of class one has improved his grip on pencil; the letters were properly sized and spaced as he did not differentiate to place the upper, middle and bottom case before intervention. He became quite efficient to complete his writing task on worksheet. He used eraser to erase the words two times only. He completed the task independently. He scored 12 out of 30 for his writing performance by utilizing rubric.

\section{Case 2}

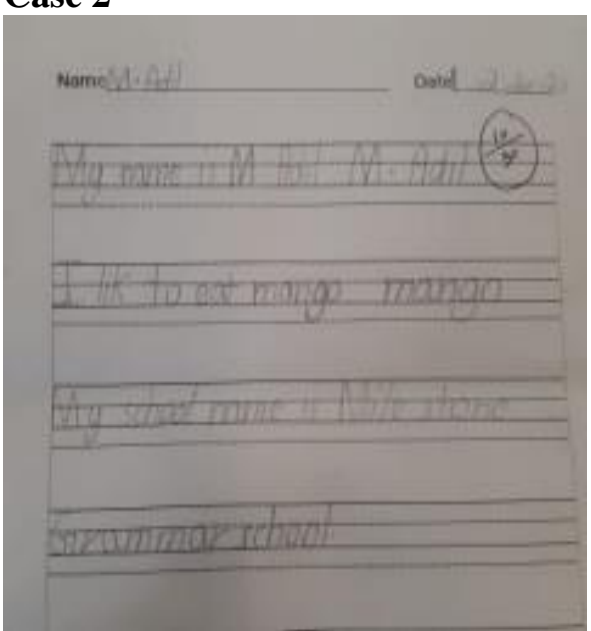

Pre-intervention

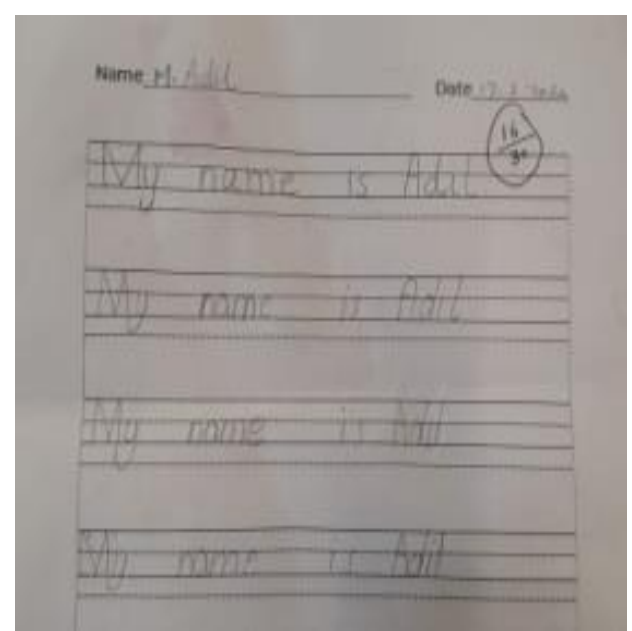

Post-intervention

Abid, was student of class one. After intervention, he was starting and ending the letters appropriately. He was scored 16 out of 30 for his writing performance by 
utilizing rubric.

\section{Case 3}

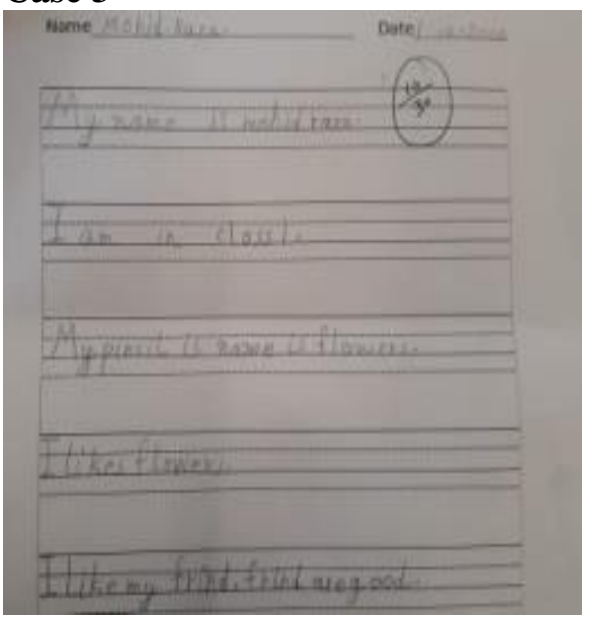

Pre-intervention

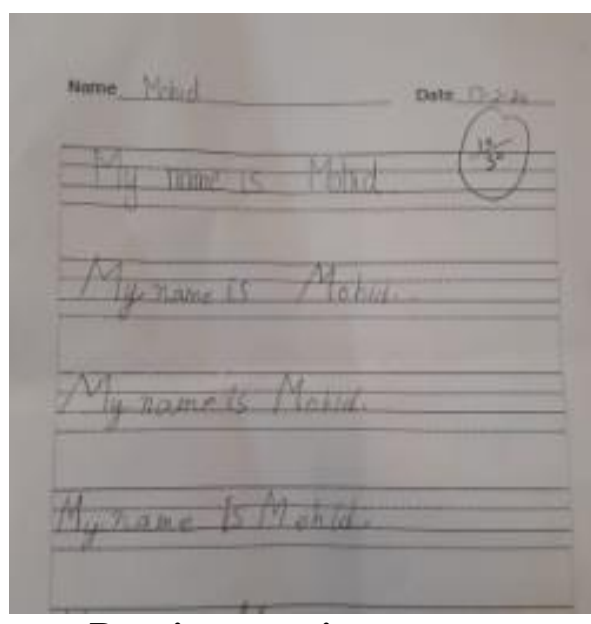

Post-intervention

As shared earlier that Razaq was little different from others as his writing was eligible when he was writing a sentences with having three to four words but as he was directed to write sentences having five to six words he lost to write in proper size and place as result his legibility of writing was decreased. He was scored 10 out of 30 for his writing performance by utilizing rubric. He did not show any improvement in his writing as compare to others.

\section{Case 4}

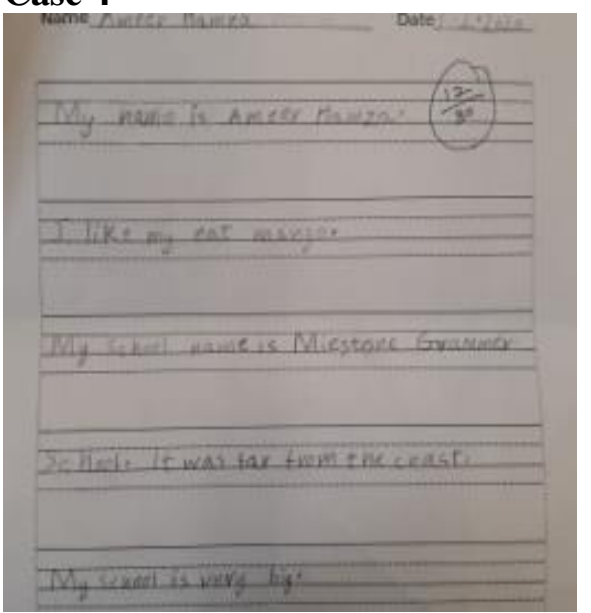

Pre-intervention

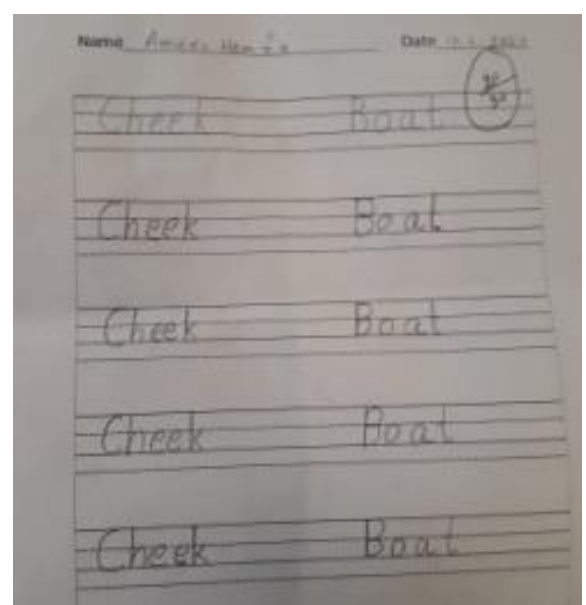

Post-intervention 
Abdul Hadi was also the student of class one. His writing was now legible as the words were properly sized as well his starting and ending of letter formation was proper. $\mathrm{He}$ got scored 20 out of 30 for his writing performance by utilizing rubric.

\section{Implication of Action Research in Classroom}

This study was appropriate in aspect of action research because action research cycle helps in identifying the problems in teaching and improving the handwriting of students through action research cycle. Development of skills at junior level needs special attention. This study is applicable in perspective of classroom action research because it helps to improve the English handwriting of first grades students through different handwriting parameters by utilizing Fine Motor skills. It describes that students cannot get grip on pencil without practicing fine motor skills. This study suggests that handwriting may be improved through repeated cycles of interventions. It is the classroom teacher responsibility to implement different handwriting patterns purposefully and utilize different fine motor skills on regular basis so that handwriting of students may be improved according to set criteria. It is suggested that fine motor skills should be purposefully added in the syllabus of junior classes.

\section{Intervention Pictures}

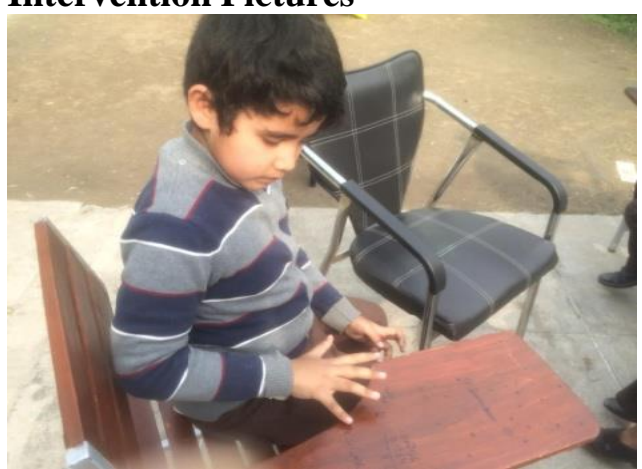

Playing the Piano

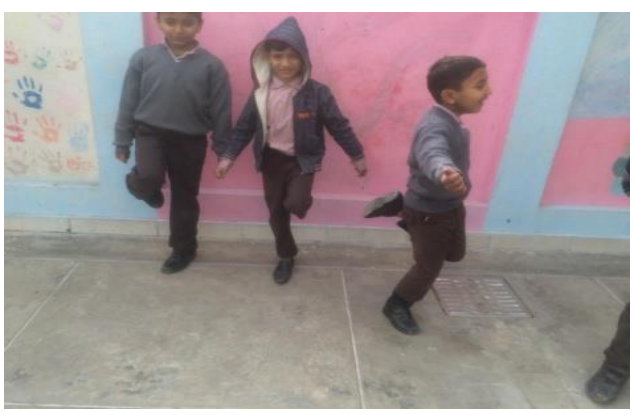

Stretching Fingers

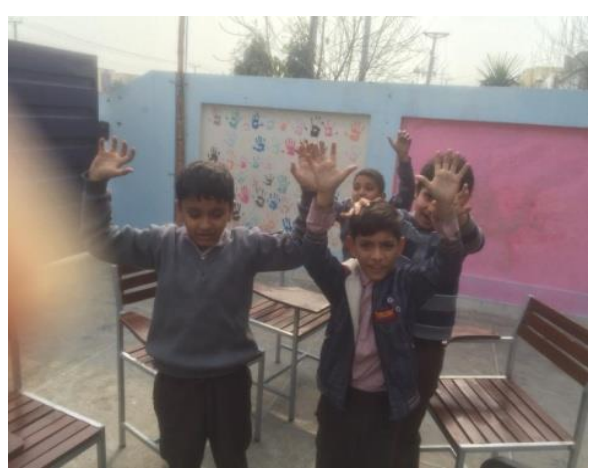

Firework

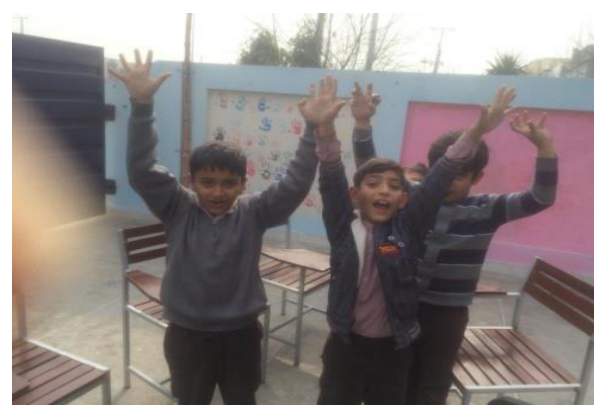

Firework 


\section{RECOMMENDATIONS}

The following recommendations are given

1. The teachers should be trained fine motor skills to improve the hand writing of students.

2. The fine motor skills should be integrated in the curriculum for early classes.

3. The fine motor skills may be used not only in English but in other languages as well to improve students hand writing.

\section{REFERENCES}

Cameron, C., Brock, L., Murrah, W., Bell, L., Worzalla, S., Grissmer, D., \& Morrison, F. (2012). Fine Motor Skills and Executive Function both Contribute to Kindergarten Achievement. Child Development, 8(4), 1229-1244. doi:10.1111/j.14678624.2012.01768.

Dinehart, L. H. (2015). Handwriting in Early Childhood Education: Current Research and Future Implications. Journal of Early Childhood Literacy, 15(1), 97-118.

Guidelines for Handwriting Instruction: Printing and Cursive Kindergarten to Grade 6. (2012). Department of Education \& Early Childhood Development: Canada.

Handwriting. (2016). Department of Education. Retrieved from www.education.tas.gov.au

Handwriting in the 21st Century? Research Shows Why Handwriting Belongs in Today's Classroom: A Summary of Research Presented at Handwriting in the 21st Century? An Educational Summit. (2012). Saperstein Associates, p (2). http://act.zanerbloser.com/v2/files/H2948_HW21Summit_white_paper.pdf.

Hill, S. (2006). Developing Early Literacy: Assessment and Teaching.Prahran, Victoria: Eleanor Curtain Publishing.

Marr, D., Windsor, M. M., \& Cermak, S. (2001). Handwriting Readiness: Locatives and Visuomotor skills in the Kindergarten Year. Early Childhood Research and Practice, 3(1). http://ecrp.uiuc.edu/v3n1/marr.html.

Marr, D., Cermak, S., Cohn, E. S., \& Henderson, A. (2003). Fine Motor Activities in Head Start and Kindergarten Classrooms. American Journal of Occupational Therapy, 57(5), 550- 557.http://dx.doi.org/10.5014/ajot.57.5.550.

Megaiab, M-M.A. (2014). The English Writing Competence of the Students of Indonesian Senior High School. Indonesia: Paper Presented at WEI International Academic Conference. Indonesia.

Ministry of Education. (2007). Literacy Learning Progressions: Meeting the Reading and Writing Demands of the Curriculum (Draft for Consultation). Wellington: Learning Media. Occupational and Physical Therapy Department. (2009). Maxanna Learning Systems: Classroom Remedial Strategies for Handwriting Difficulties.

Renwick, W.L. (2008).Teaching Handwriting. New Zeland: Learning Media.

Schickedanz, J.A. (1999) Much More than the ABCs: The Early Stages of Reading and Writing. Washington, DC: National Association for the Education of Young Children.

Snow, C., Burns, S., \& Griffin, P. (1998). Preventing Reading Difficulties in Young Children. Washington, DC: National Academy Press. 